\title{
Character Educational Value of Stephen Hawking in the Theory of Everything Movie Directed by James Marsh
}

\author{
Tati Mardewi, Endra Wanto, Furi Indriyani \\ Universitas BSI Bogor, West Java \\ tati.tdi@bsi.ac.id
}

\begin{abstract}
The purpose of the research is to analyze character educational values in The Theory of Everything movie directed by James Marsh. It discusses about character educational values that are shown in and depicted by Stephen Hawking. This research investigates 6 character educational values of Stephen Hawking that consist of persistent, self-confident, communicative, optimistic, curious and hard working. The Theory of Everything is a perfect movie for analyzing character educational values, as it tells about Stephen Hawking' life who tries keeping himself on fire even though there are so many inside and outside obstacles. According to Afandi in(Budihardjo, 2017) "Character education is an education system with invest values accordance with the nation's culture and knowledge aspects, feels of affection, and actions, both against Almighty God either for themselves, the communities and the nation".It means character education values involves developing sensitivity to be good and enables to choose the right values in accordance with the thought and action. So character educational values that are shown by Stephen hawking can make us know how to be success to reach our ambition.
\end{abstract}

Key words: Character Educational Value, Character Educational Value's types, The Theory of Everything movie

\section{INTRODUCTION}

Literature is the materials or a source of scientific that used to make a paper or other scholarly activities. Literature is form of human expression that expressed in words such as poem, novel, and journal. It is not only in writing but also in the form of movie, cassette, record and many more. Based on(Yastanti, U. Widhiyanto, 2018), "Literature is a uniquely human activity, born of man's timeless desire to understand, express, and finally share experiences". It meansthe literature has many forms both written and unwritten. There are many kinds of literature, such as poetry, novel, autobiography and many other fiction or nonfiction works. Movie is as also known as film is to express and to be a large part of people knowledge and awareness. Movie is a modern art that made for business and entertainment. Movie is used to convey a specific message from the author.Based on (Safranj, 2015), " Movies are motivating media due to encompassing various topics and they are presented with both audio and visual". It means that movies can also be considered as part of human artwork expressed in visual and audio. Besides that a movie canbe as a medium of communication and a good educator through the message contained in it. It is explained that movie is a part of moving picture contain shot and frames called animated. There are a lot of aspects can be found in a movie such as character, plot, 
setting, theme, and point of view. The aspects that would like to describe in this research is character. Character is personality which makes someone look different from others. Character is inner nature that is affected a mind, behavior, norm which have by a human. According to Koesnosobroto in(Pangestu, 2019)“Characters can be divided into two kindly major or main character and minor character. Major character is the most important character in a story. Basically, story is about main character, but main character cannot stand alone, main character needs other characters to fill the story to be more convincing and feels alive". From the definition above, it means that a character plays an important roleand italso needs other roles such as the existence of the supporting roles for success. So the story can be more interesting and relatable because film without character seems flat.

Character educational values are essential values in every aspects of life. They help people to accomplish and reach their goals in any conditions and situations.(Khoirina, Suyitno, \& Winarni, 2017)states that character education is the process of forming the personality, psychology, and physical structure in a balanced relationship. The process is done to anticipate the influence of the outside is not good. In general, character education is to protect oneself and form personality independently based on certain beliefs individual or group as well as nation and state. According to Lickona in(Agung, 2018), "Character education is a plus moral education, which include the cognitive, emotion, and action aspects, without these three aspects, the character education would not be effective". From the explanation above character educational value can be defined as a system that is shown by instilling high values, morals, ethics and culture.

The Theory of Everything movie directed by James Marsh, is starred by a talented actor, singer and model from London, Eddie Redmayne. This movie is not like movies on televisions and theaterswhich contain a lot of violence or pornography, it delivers so many character educational values such as hard working, persistent, communicative, and, etc. The characters of educational values that are shown by Stephen Hawking are started when he is a physics PhD student at Cambridge tries proving his idea about black holes. Stephen's life is not easy when doctors diagnose him with amyotrophic lateral sclerosis, an incurable progressive degenerative motor neuron disease. The disease will cause his physical condition getting worse day by day and his life will only for two years left. These do not make him stop his dream to prove about the idea of black holes. He is still on fire every single of his life. He refuses unpleasant odds about his disease and breaks new area of knowledge in the fields of medicine and science. He achieves more than he can hope to imagine in his limitation.

So this movie shows Stephen Hawking's character educational values that educate people to stay giving their best in their lives in any kinds of conditions and situations.

\section{METHOD}

In this analysis, the writer uses descriptive qualitative method. (Sukmadinata, 2011)states descriptive qualitative research is intended to describe the existed phenomena that are natural or human engineering. It pays more attention to the characteristic, quality, and activity interrelationship. The procedure of the analysis has some steps. The writer collects the data and material with variety of resources such as books, journals, articles and other references. The primary resources of this 
research are from the movie itself, The Theory of Everything directed by James Marsh. After watching the movie and collecting the data, the writer studies about the whole story about before continuing to the next step, then analyses the story is all about, including the character educational values that the writer is able to take from the movie.

\section{RESULT AND DISCUSSION}

\section{Summary of the Story}

The Theory of Everything movie is directed by James Mars. It tells about the story of Stephen Hawking, an astrophysics student who starts an adoring connection with a literature student, Jane Wilde. Although they are shy at first, but they both get closer day by day.Unfortunately, in one morning, Stephen falls and his head crushes hard in his university yard. Doctor checks him and he is known that he has nerve cell disease, his muscles will deteriorate and his life is only for two years more. Stephen thinks to shut Jane off from his life but Jane insists on marrying him. Stephen and Jane's family try to persuade Jane by saying their fears about Stephen illness.

Stephen and Jane have got married then. They have three children. When Stephen graduates his PhD viva and works as a lecture, he makes great progressabout his idea, black holes but his physical condition is getting worse. He is inability to speak or walk. Jane looks after him by feeding, taking a bath and everything that Stephen needs. Jane feels tired because of that but Stephen dissagrees to get external help.

Jane feels stressed and her mother considers about that. She suggests Jane join a church choir. Jane feels happy joining the choir and meets, a widower, Jonathan. Jonathan becomes her close friend and private piano teacher for her son. Jonathan is not only kind to Jane but also to her entire family and Stephen.Stephen and his mother knows that Jane and Jonathan have feeling each other. That is why Stephen's mother ask Jane if the third child of her is Jonathan's.

Stephen chooses to go with his friends to a concert in France. But as the music plays, he coughs blood and faints, suffering from pneumonia and put on life support. Jane, who is on a camping trip with her children and Jonathan, arrives in France and agrees to the surgery as Stephen's life is important to her. Doctors must operate on his throat for saving Stephen's life but the operation ends his speech power.Stephen must learn to communicate through a spelling board. Jane and Stephen's life gets harder.

Stephen hires a nurse, Elaine. He uses a spelling board for communication. A computer with a built-in voice synthesizer becomes his tool to helps him give voice to his thoughts. Meanwhile, Stephen research about black holes gets global accolades but his marriage is in trouble. Stephen knows that Jane is not fully happy with this marriage. He thinks Jane starts to like Jonathan. That is normal as Stephen's thought. Stephen talks about this to Jane. They make an agreement to get divorce. Then Jane and Jonathan get married.

Stephen decides Elainne to accompany him on a lecture tour to America. In America, Stephen addresses eager students. Someone asks him his philosophy of life and as he movingly imagines being physically able, he says life is about 
hope, courage and human endeavor, to which there is no boundary.

Stephen Hawking is invited by the Queen to be honored. He asks Jane and their children to accompany him. The couple sit in a garden and smile when Stephen indicates the children and says, "Look at what we made."At the end of the movie, Jane finally finishes her $\mathrm{PhD}$ and Stephen is still continuing his research.

\section{Analysis of Character Educational values in the Story}

Thecharacter educational values analysis in The Theory of Everything movie directed by James Marsh belongs to six types of character educational values. There are; persistent, self-confident, communicative, optimistic, curious and hard working.

\section{Persistent}

Persistence has become one of the everyday character educational value that can enable people to succeed in life. It gives ways to deeper understanding that attaining long-term and higher-order goals. Persistence depends on how people deal with inevitable obstacles.In this scene, Stephen Hawking's persistence is tested by some scientists. Some of them do not believe in his theory, black holes, for the first.Stephen still explains his theory smartly and persistently. The persistent act of Stephen Hawking in The Theory of Everything movie that is shown through the following scene.

\section{Scene 1}

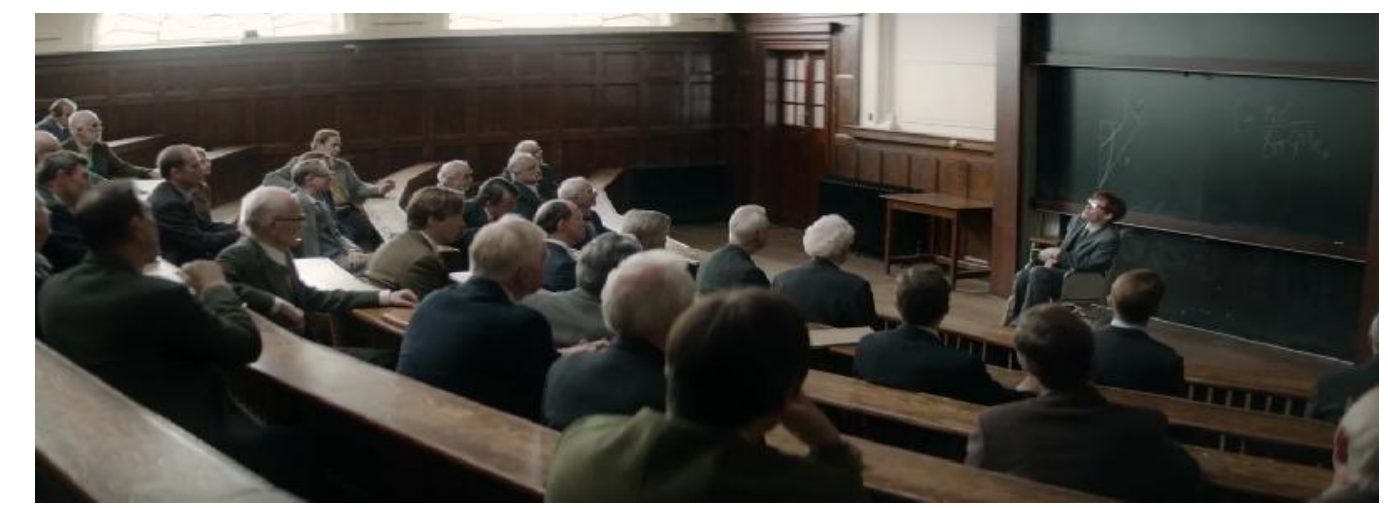

Source: The Theory of Everything Movie

Figure III.1

Stephen presented his ideas at the conferences.

Stephen : :Allowing us to predict that some particles can in fact escape a black hole. Black holes aren't black at all, but glow with heatradiation."

Sciema : "He's unifying Relativity plus Quantum Mechanics and Thermodynamics. For the first time."

John Taylor : "Thermodynamics? Last used to describe the steam engine."

Stephen : "In other words--the steady emission of heat energy causes black holes to slowly lose mass, they evaporate, eventually disappearing in a spectacular explosion. So..."

Brian : "No-no! What he's saying is just as a hot. Body loses heat, right?" 


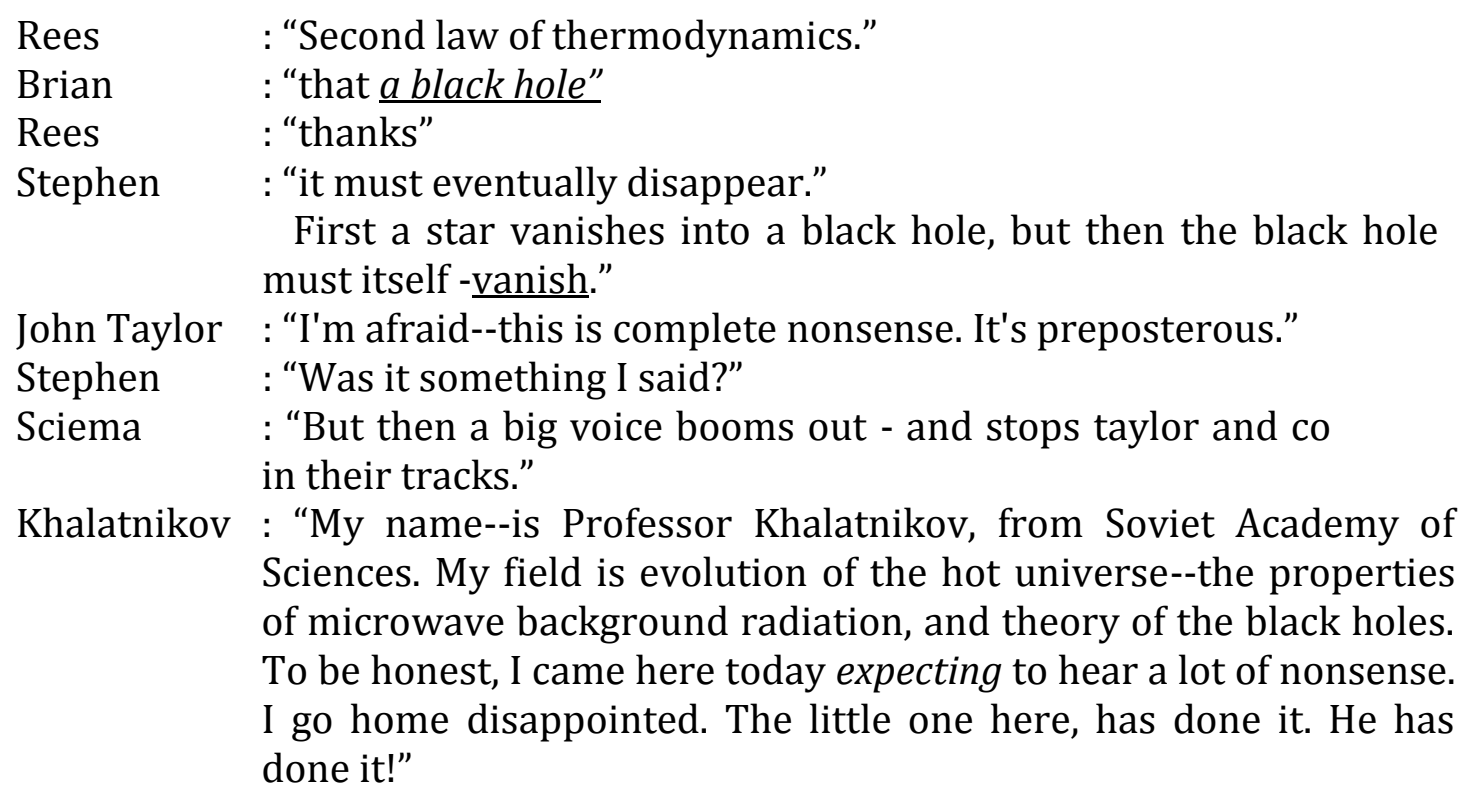

(At minutes 0:49:52-0:52:28)

Based on the Picture and the dialogue above that happen at Lecturer hall, Cambridge University in the afternoon.Stephen Hawking conveys his idea about black holes that may have been a part of the creation of universe.By sitting on his wheel chair, Hawkingpresents the theoryin front of other scientists.The scientists deny his explanation about the theory for the first but Hawking still prove his idea by explaining it smartly and persistently.

What Stephen overcomes and what he goes on to accomplish is beyond extraordinary and completely inspiring. He refuses to give up continuing and finishing his explanation about theory black holes inspite of his health condition is the personification of persistence.

From the analysis above, the writer concluded that character educational values that shown by Stephen Hawking is persistentwhen he always attempts to develop and Finish his explanation about the theory, black holes.

\section{Self confident}

Self confidence is one of the most important aspects in character educational values. It help people to stand alone, to feel free and to be aware of their strength as well as to face everything in their lives.A confident person knows through hard work and peristence that most situations can have good outcomes. In this scene, Stephen Hawking shows about it.The self cofident act of Stephen Hawking in The Theory of Everything movie that is shown through the following scene. 
Scene 2

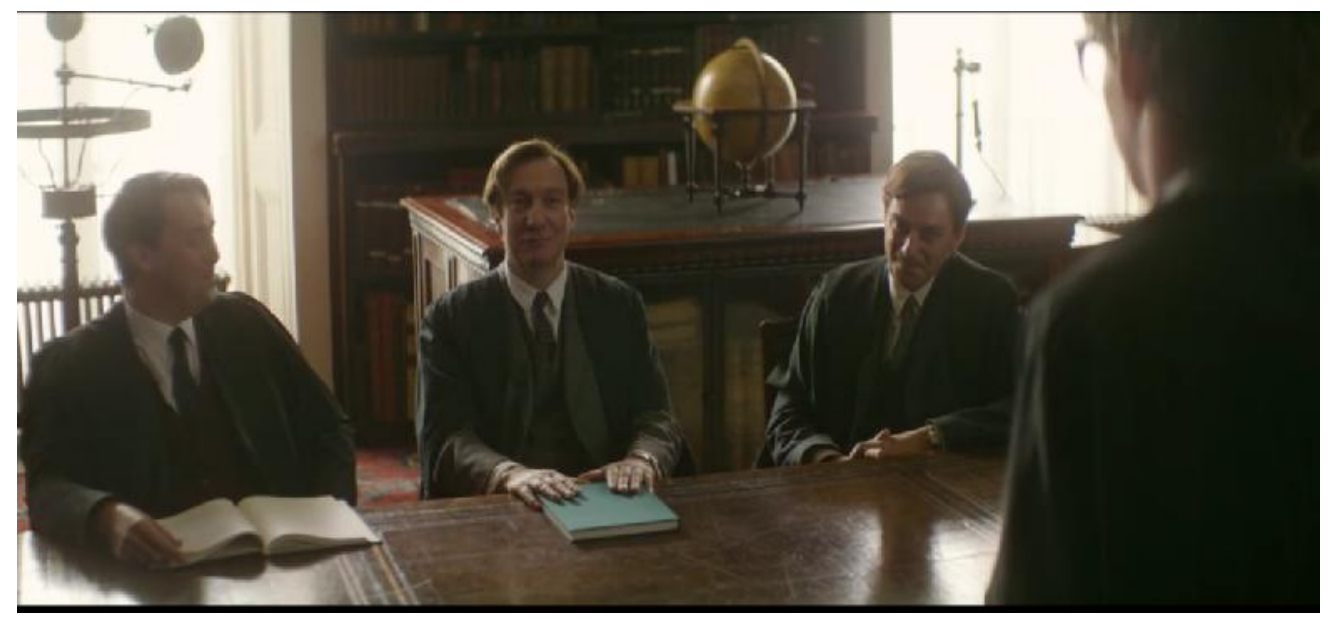

Source: The Theory of Everything Movie

Figure III.2

Stephen Presented his thesis in thesis defense.

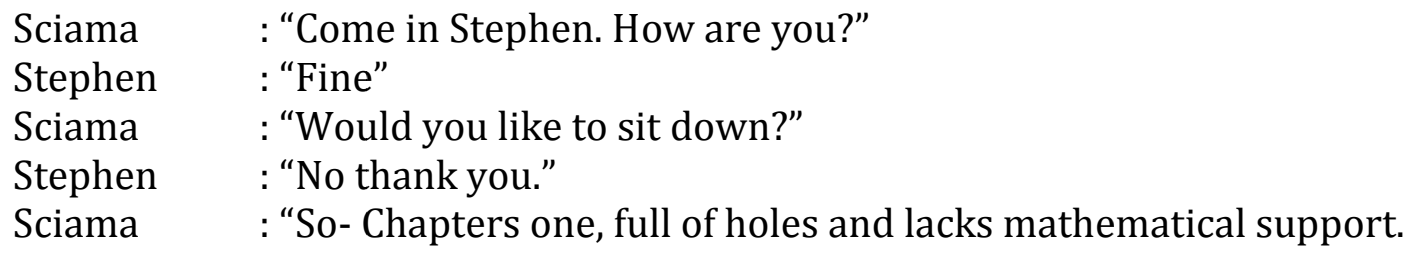

(to kip Thorne) Professor Thorne?"

Kip throne : "Chapter two not really original" Uses a lot of roger's ideas.

Penrose : "Well at least you run with them. Chapter three? Too many unanswered Questions."

Sciama : :But four? A black hole at the beginning of Time."

Kip throne : "A space time singularity?"

Sciama : "Brilliant. It's brilliant Stephen. So all that remains to be said is...well done. Or should I say, well done doctor. And extraordinary theory."

Stephen : "Thank you"

Sciama : "So, what now?"

Stephen : "Prove it. Prove...with a single equation, that time has a beginning. Wouldn't that be nice professor? One single elegant equation to explain everything?"

Sciama : : "Yes. It would. It would indeed."

(At minutes 0:40:00 - 0:42:00)

Based on the Picture and the dialogue above, they show Stephen Hawking's self cofidence in responding examiners' questions in his thesis defense. One of of examiners, Sciama, checks his thesis. Sciama amazes to the Hawking's theory about black holes at the beginning of time. Stephen Hawkingtells confidently that he wants to prove the theories with an elegant equation to explain everything.

From the analysis above, the writer concluded that character educational values that is shown by Stephen Hawking is self confidence, when he responds all the 
examiners' questions wihouth doubt to prove his idea about black holes.

\section{Communicative}

Comunicative is an act that shows the pleasure of speaking, associating and cooperating with others. Stephen Hawking shows his communicativeness from his dialogue with the audience in his seminar. He responds all audiences' questions with arranging of his amazing sentences.The communicative act of Stephen Hawking in The Theory of Everything movie that is shown through the following scene.

Scene 3

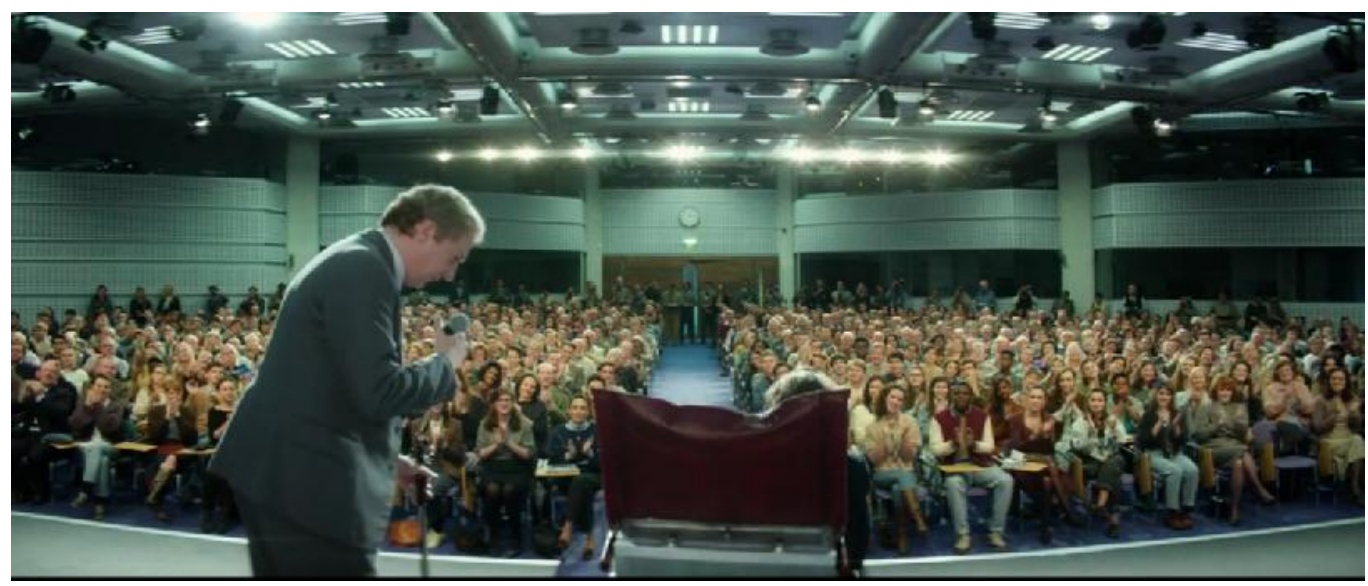

Source: The Theory of Everything Movie

Figure III.3

Stephen answered a question from guests

\begin{tabular}{|c|c|}
\hline ciama & : "The first pre-selected question, please!" \\
\hline Guest 1 & $\begin{array}{l}\text { : "How have you been able to deal with all the physical challenges } \\
\text { you face?" }\end{array}$ \\
\hline Stephen & $\begin{array}{l}\text { : "Can you hear me? (The audience laughter) } \\
\text { There are some things I cannot do. But. They are mostly the } \\
\text { things I don't particularly want to do anyway." }\end{array}$ \\
\hline Guest 2 & $\begin{array}{l}\text { : "Now you are recognized everywhere, how do you deal with all } \\
\text { the attention?" }\end{array}$ \\
\hline Stephen & $\begin{array}{l}\text { : "I was stopped recently by a tourist in Cambridge who asked if I } \\
\text { was 'the real Stephen Hawking.' I replied that I was not, and said } \\
\text { the real one was-much better looking. (The audience laughter) } \\
\text { He believe me." }\end{array}$ \\
\hline Guest 3 & $\begin{array}{l}\text { : "In } 1979 \text { you talked about the possibility of a The Theory of } \\
\text { Everything being discovered before the end of the century." }\end{array}$ \\
\hline Stephen & : "I now predict -- that I was wrong." \\
\hline Guest 4 & : “Is Time Travel possible?” \\
\hline Stephen & $\begin{array}{l}\text { : "I have experimental evidence that Time Travel is not possible. } \\
\text { I gave a party for Time-Travellers but no-one came." (The } \\
\text { audience laughter) }\end{array}$ \\
\hline
\end{tabular}

(At minutes 1:48:30 - 1:52:15) 
Based onthe Picture and the dialogue above, Stephen Hawking shows a character educational value, communicative. This is proved by his pleasure of speaking by telling "I was stopped recently by a tourist in Cambridge who asked if I was 'the real Stephen Hawking.' I replied that I was not, and said the real one was-much better looking" and "I have experimental evidence that time travel is not possible. I gave a party for Time-Travellers but no-one came." The two responds of Hawking that make a friendly and communicative action with others.

From the analysisabove, the writer concluded that character educational values that is shown by Stephen Hawking is comunicative.

\section{Optimistic}

Optimism is the faith that leads achievement. Being optimistic,people can improve the quality of life. They tend to look on the bright side of things and think positively about life and believe in any situations and conditions.TheOptimistic act of Stephen Hawking in The Theory of Everything movie that is shown through the following scene.

Scene 4

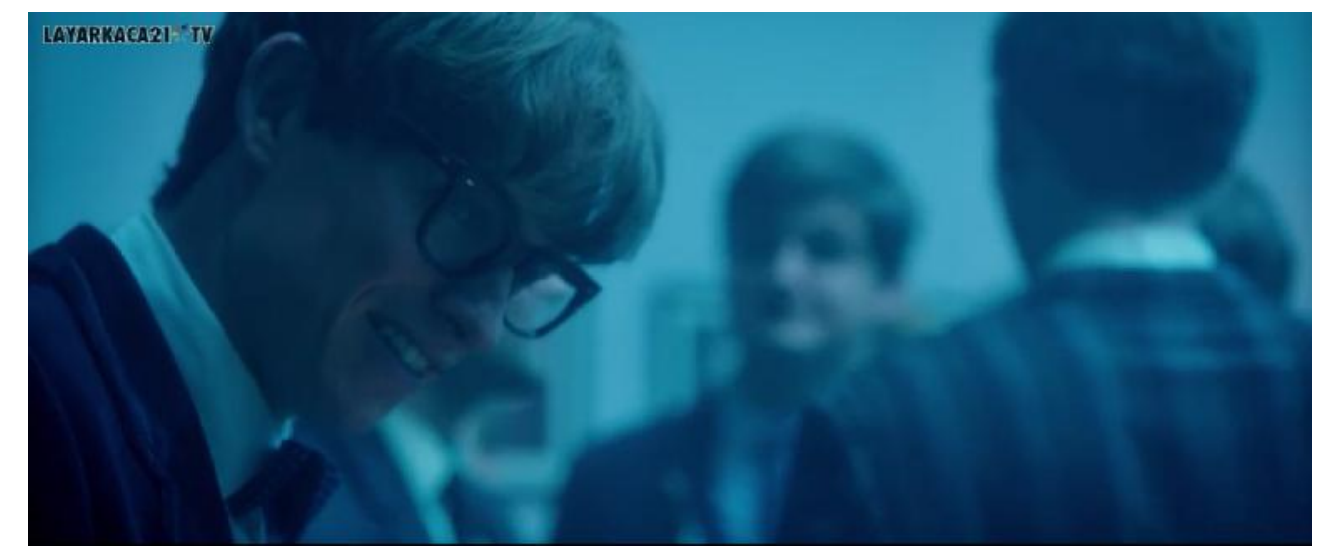

Source: The The Theory of Everything Movie

Figure III.4

Stephen told his goals to Jane.

\begin{tabular}{|c|c|}
\hline Stephen & : “Hello" \\
\hline Jane & : “Hello" \\
\hline Stephen & : "Science" \\
\hline Jane & : "Arts, So what do you?" \\
\hline Stephen & : “Cosmologist. I'm a cosmologist.” \\
\hline Jane & : "What's a cosmologist?" \\
\hline Stephen & $\begin{array}{l}\text { : "It's a kind of religion-for intelligent atheists. You're not } \\
\text { religious, are you?" }\end{array}$ \\
\hline Jane & : "C of E. Church of England." \\
\hline Stephen & : "England. I suppose someone has to be." \\
\hline Jane & : "So--what do cosmologists worship then?" \\
\hline Stephen & $\begin{array}{l}\text { : "A single unifying equation that explains everything in the } \\
\text { universe." }\end{array}$ \\
\hline Jane & : "Really? So what's the equation?" \\
\hline Stephen & : "That is the question. the amazing equation, but I will find out." \\
\hline
\end{tabular}

(At minutes 0:03:27 - 0:04:10) 
Based on the Picture and the dialogue above, the writer analyzes that in the evening at students' party in Cambridge University. Brian walked off to talk another girl, while Stephen left alone, decided to approach Jane slowly. Jane had hardly touched her wine. Stephen had a beer. They looked around the room together, and then they took a dialogue. The part of the dialogue that shows Stephen's optimism is when Jane asks about cosmologist worship, Hawking answers optimistically that a single unifying equation that explains everything in the universe. Another part is when Hawking says he would fnd the amazing equation optimistically.

From the plot of scene above the writer concluded that character educational value that shown of Stephen Hawking is optimist.

\section{Curious}

Cduriousity is the attitude and action that always try to know deepper and extends from something learned, seen, and heard. Curious acts of Stephen Hawking inThe Theory of Everythingmovie that are shown through the following scene.

Scene 5

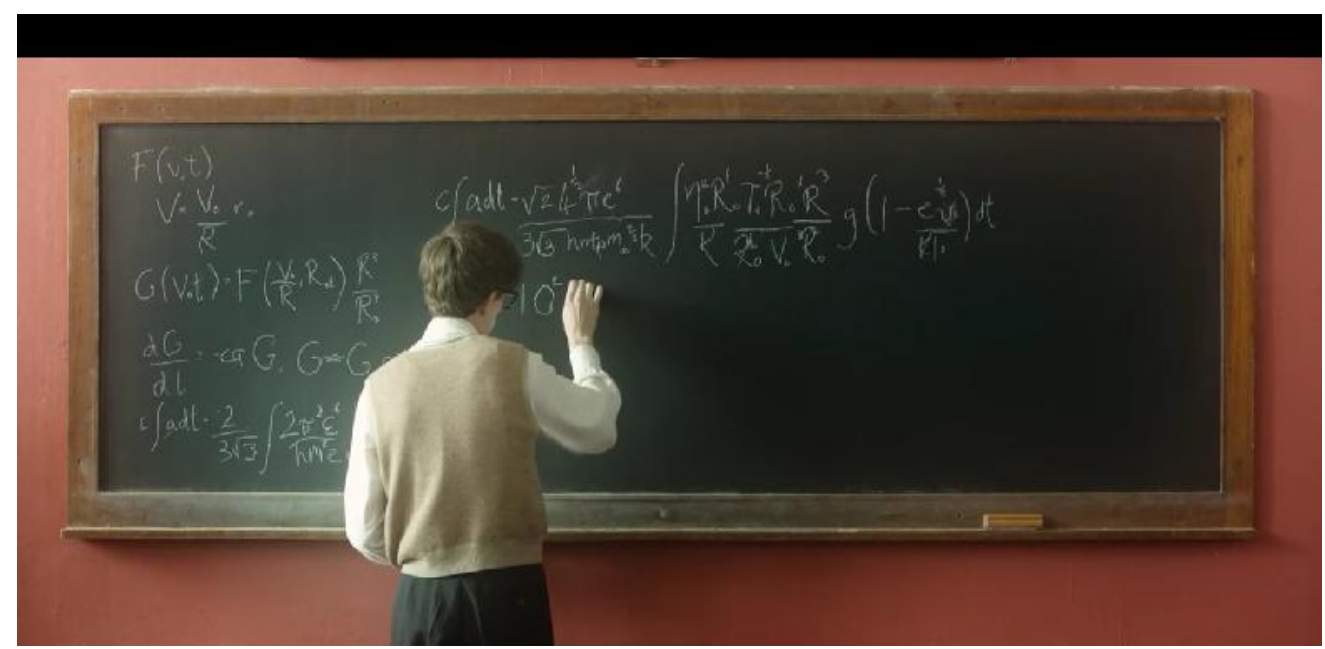

Source: The Theory of Everything Movie

Figure III.5

Stephen tries breaking equation about his theory

Stephen : "If-if so If Einstein is right, if general relativity is correct, then the universe is expanding, yes"?

Jane : "Alright"

Stephen : "which means that, if you reverse time, the universe would get smaller and smaller. So what if-if I reverse the process all the way to see what happened at the beginning of Time itself? The universe, smaller and smaller, denser and denser, hotter and hotter as we approach its birth. Wind back the clock"

Jane grabs his hands and begins to swirl him around.

Stephen : "What are you doing"?

Jane : "Winding back the clock"!

Stephen : "Is that what you're doing"? 


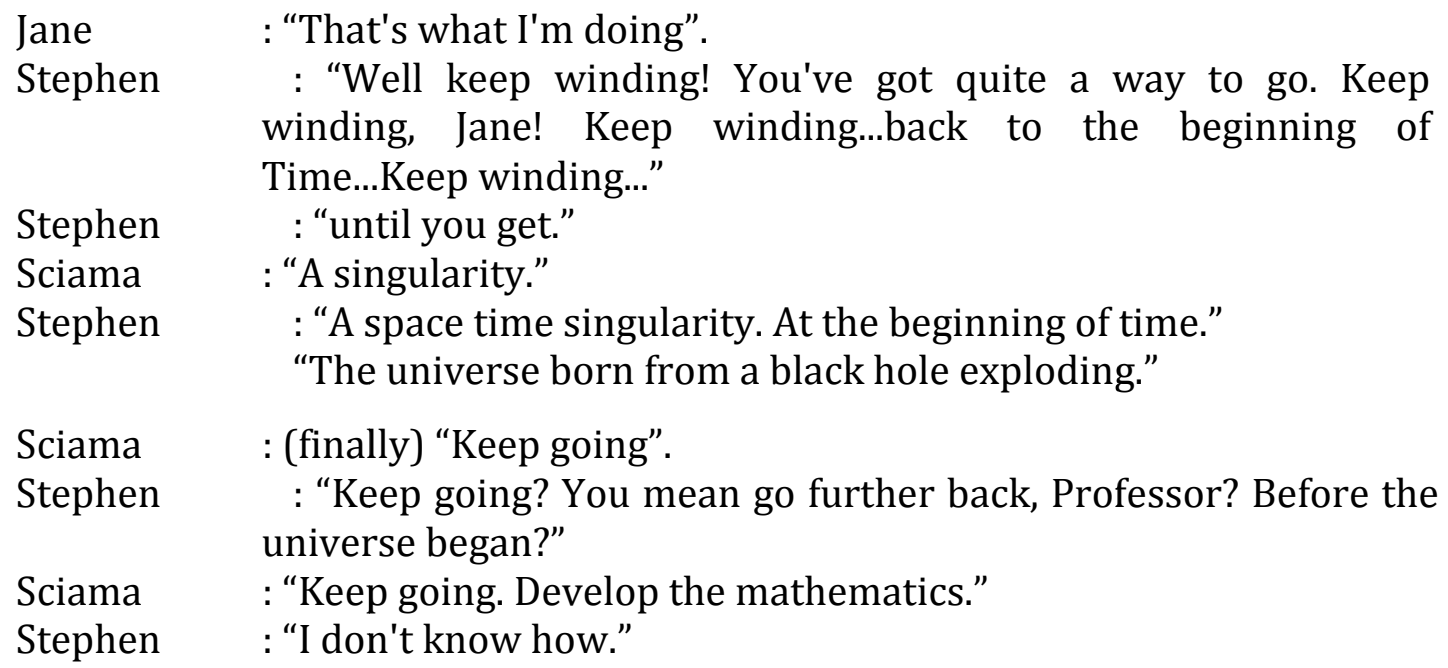

Based on the picture and the dialogue above, Stephen Hawking shows character educatioal value, curiousity. Stephen Hawking has a high curiosity about black holes. It is proved when he writes a formula on the blackboard. He stops, thinks, continues, then deletes, and writes again, faster, and faster to develop his curiousity. When Stephen and Jane walk side by side in river bank, he expands on his idea by telling some possibilties and asking many questions about black holes.

From the plot of scene above the writer concluded that charactereducational values that are shown by Stephen Hawking iscuriosity.

\section{Hard working}

Hardworking is an important point of character educatioal value. It is a behaviour that shows earnest effort in overcoming barries to learn and complete the task as well as possible. The character educatioal value, hardworking in The Theory of Everything is shown through the following scene.

Scene 6

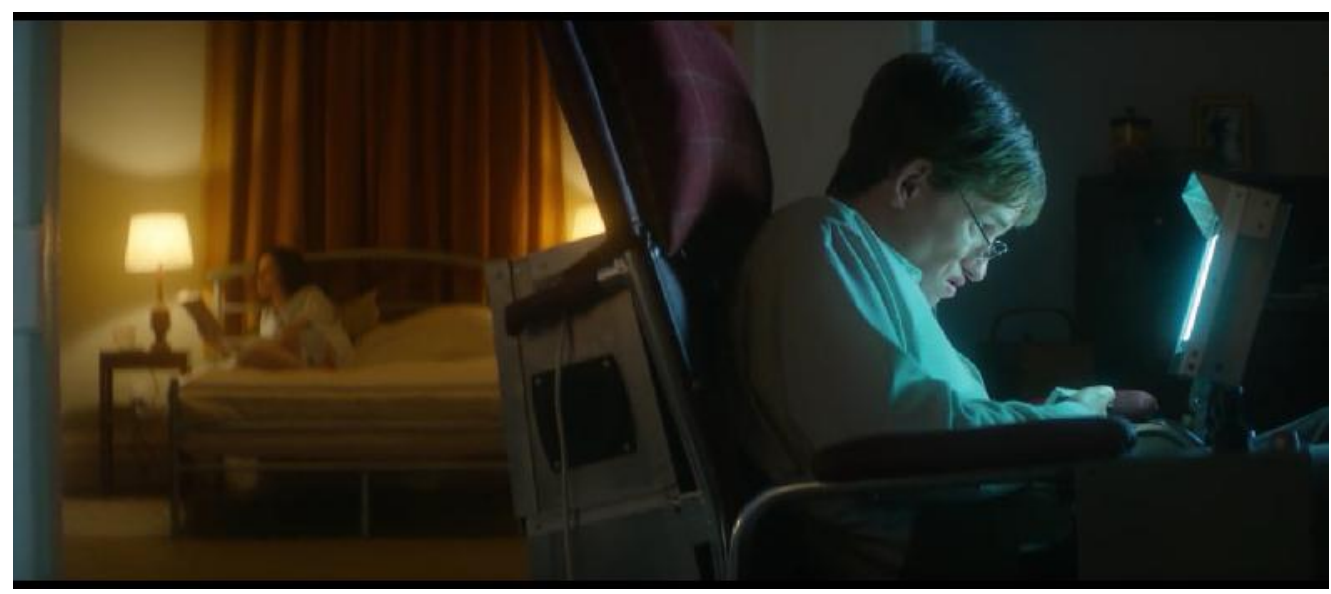

Source: The Theory of Everything Movie

Figure III.6

Stephen wrote a book. 
Based on the picture above,Stephen Hawking is a hard working person. He shows this in his daily life. It is proved in this scene when he learns and writes his book "History of time" till night. He makes a concept and record it. He is always on unyielding spirit in his unwell condition because of his deaseas. Most of his life is full of great activitiesto break his idea about Black holes.

\section{Result}

In this research, the writer analyzes six types of charactereducational values in The Theory of Everything movie directed by James Marsh. There are persistent, selfconfident, communicative, optimistic, curious and hard working. The data are collected by the conversations in the movie's scenes. It is between characters in the movie. From the data, there are utterances and actions that Stephen Hawking has said and doneto describesix types ofcharacter educational values. In this research, the writer analyzessix types of character of educational values. There are persistent, self-confident, communicative, optimistic, curious and hard working..

Persistentis a view that human have ability to become much better in their lives when they achieve what they want to be. The achievement has to be full of spirit and effort. It becomes complicated if people easy to give up.

The flow of this state of persistence makes Stephen knows what he wants in difficult conditions. Stephen should prepare himself to compete by his own self to show the world that he can face the difficult situation by his theory.In this category, the writer finds three haracter educational value of persistencefrom the scenes of the movie. It is proved through Stephen Hawking conversationthat describes his persistece when he always attempts to develop and finish his theory about black holes which may have been a part of the creation of universe.

Self confident means how to be comfortable with ourselves, event thought there are so many things that happened to us. It starts insideof our thinking and then it will influence our feeling. In this category, the writer finds three caracter educational value of self confidence from the scenes of the movie. It is proved that in the afternoon at seminar room, Trinity hall, Cambridge. Stephen faces Sciama, Roger Pen Rose and Kip Thorne. He presents his thesis in front of the three examiners. They proved of Stephen thesis. Sciama said, "Brilliant. It's brilliant Stephen. So all that remains to be said is well done. Or should I say, well done doctor. And extraordinary theory." Stephen sighted with relief and smiled. And he said confidently, "Prove it. Prove...with a single equation, that time has a beginning. Would not that be nice professor?. One single elegant equation to explain everything?" Finally Stephen got a Doctor degree.

Communicativeis an important item that will demonstrate kind and thoughtful to other people. It can be shown by your smile, tone voice, sentece arragement or your body language. And we need to be comunicative as social human being. In this category, the writer finds onecharacter educational value of comunicativefrom the scenes of the movie. Stephen proved his comunicativeness when he answered a guest question in his seminar, a guest ask, "now you are recognized everywhere, how do you deal with all attention?." Then Stephen answered that question "I was stopped recently by a tourist in Cambridge who asked if I was 'the real Stephen Hawking.' I replied that I was not, and said the real one was much better looking, He believe me." After that the other guest asked to Professor Stephen hawking too, And He answered. 
The ways his responds the guests' questions show he is communicative person.

Optimistic could be related to feel confidence. How can you believe in what you do with consideration and knowledge. The result of optimism is successful outcome of things in the future. Feeling optimism is not only in good situation but also in bad situation. The opposite of optimism is pessimism. We have to avoid of pessimism, because of God gives us brain to think. By thinking, we can arrange success to be optimism. Optimism can develop our lives to be better. In this category, the writer finds onecharacter educational value of optimism from the scenes of the movie. It is proved in the evening at students party in Cambridge, Stephen and his friend, Brian have beer. A few minute later Brian walk to her girl leaving Stephen alone. Stephen decide meet Jane. They looked around the room together, and then they took a dialogue. Stephen is Cosmologist. Jane asks Stephen "what is cosmologist". Then Stephen answers Cosmologist is a religion from Stephen, and he is optimistic that he can discover a single unifying equation that explains everything in the earth and outer space.

Curious is a strong desire to learn and to know about something. Sthephen Hawking shows this character educational value when he presents his idea about black holes. he does not stop asking and giving so many posibilities about black holes. his curiosity can be shown by his conversation with Jane, his lecturers, friends and seminar audiences. Stephen's curiosity is proved on the scene when hetries breaking this idea of black holes by writing the ways of black holes' possibilityon the blackboard. He stops, thinks, continues, then deletes, and writes again, faster, and faster to develop his curiousity. When Stephen and Jane walk side by side in river bank, he expands on his idea by telling some possibilties and asking many questions about black holes. What Stephenshows on the scenes of The Theory of Everythigmovie are character educational values, curiosity.

Hard working is one of thing for succeeding. Without hardworking, we cannot get the success. It appears after we know the aim of our passion. In this category, the writer finds one character educational value of hard working from the scenes of the movie. It is proved by Stephen when he continues his writing and learning the book "History of time" till night. His codition does not make him stop to do that.

\section{CONCLUSION AND SUGGESTION}

\section{Conclusion}

Referring to the previous analysis, the writer focused on character educational values of Stephen Hawking in The Theory of Everything movie directedby James Marsh. The writer found six types of character educational values. There are persistent, self-confident, communicative, optimistic, curious and hard working. Persistentis shown in the scene of movie when Stephen tries breaking equation about his theory, black holes.Hawking presents his idea at the conferences, and then hetells Jane that he will write a book of history of time in unhealthy condition. Self confident is shown in the scene of movie when Stephen presentshis thesis in thesis explanation, Stephen takes a dialogue with Jane, Stephenis motoring along with Sciama. Communicative is shown in the scene of movie when Stephen answers questions from guests in conferences. Optimisticis shown when Stephen Says to Jane that he will found a single unifying equation that explain everything in universe.

Curious is shown in the scene of movie when he expands on his idea by telling 
some possibilties and asking many questions about black holes. The last is hard working. It is shown in the scene of movie when Stephen writes a book, the theory of time.

\section{Suggestion}

The Theory of Everything movie is a great movie. We find so many features of character educational values that can make us learn and start to improve our thought and mind to be better life. This research will open the readers, teachers and the next researchers' minds about character educational values. So that, the writer would like to give some suggestions to them.

Suggestion for the readers, by this research, it can improve the knowledge of the readers about character educational value. And the readers can practice these values to make their lives easier and better.

Suggestion for the teachers,character Educational values are essential parts in education. As teachers, we do not teach the students about the lesson material only, but we also need to give the example of character educational value in the real life in order students know kinds of educational characters that make them reach their goals. So teachers can use this research analysis to make their students understand what character educational values are.

Suggestion for the researchers, character educational value will become an interesting topic to analyze. I hope that the next researchers will get deeper analysis of character educational values from this movie.

\section{REFERENCES}

Agung, L. (2018). Character Education Integration in Social Studies Learning. Historia: Jurnal Pendidik Dan Peneliti Sejarah. https://doi.org/10.17509/historia.v12i2.12111

Budihardjo, B. (2017). The Character Education Values in Qur'anic Verses. Profetika: Jurnal Studi Islam. https://doi.org/10.23917/profetika.v17i02.5301

Khoirina, I., Suyitno, S., \& Winarni, R. (2017). Character Educational Value of Kalamata Novel By Ni Made Purnama Sari And Its Relevance For Teaching Literature In High School. Lingua Didaktika: Jurnal Bahasa Dan Pembelajaran Bahasa. https://doi.org/10.24036/ld.v11i2.7944

Pangestu, M. (2019). The Reasons Of The Main Character In Using Slang Words In Deadpool 2 Movie Directed By David Leitch. Wanastra: Jurnal Bahasa Dan Sastra. https://doi.org/10.31294/w.v11i1.4963

Safranj, J. (2015). Advancing Listening Comprehension Through Movies. Procedia Social and Behavioral Sciences, 191. Retrieved from https://doi.org/10.1016/j.sbspro.2015.04.513

Sukmadinata, N. (2011). Metode Penelitian Pendidikan. Bandung: PT Remaja Rosdakarya.

Yastanti, U. Widhiyanto, B. (2018). Persistency of The Main Character In The Revenant Movie Directed By Alejandro Gonzalez Inarritu. Progressive Journal of Lingustic, Literature and Teaching, 13, 23-34. Retrieved from https://ejournal.nusamandiri.ac.id/index.php/progressive/article/view/520 